\title{
An Evaluation of the facet joint angle characteristics on the development of lumbar disc hernia in young patients
}

\author{
Lomber disk hernisi olan genç hastalarda faset eklem açı özelliklerinin lomber disk \\ hernisi gelişimindeki rolünün araştırılması
}

\author{
Ahmet Eroğlu, İlhan Yılmaz, Metehan Eseoğlu
}

Gönderilme tarihi: 20.03.2018

Kabul tarihi: 13.07 .2018

\begin{abstract}
Purpose:The aim of the current study was to investigate facet tropism in young patients with lumbar disc hernia $(\mathrm{LDH})$ and the role of facet tropism in the development of LDH

Materials and methods:The study included 57 patients aged 20-32 years with a diagnosis of LDH and bilateral facet joint angles at L3-4, L4-5 and L5-S1 levels measured on lumbar magnetic resonance imaging (MRI) tests. In the comparison of the two facet joint angles, a difference of $<7^{\circ}$ was classified as no tropism, $7^{\circ}-14^{\circ}$ as moderate tropism and $>14^{\circ}$ as severe tropism. A control group was formed of 46 age-matched healthy individuals with no lumbar disc hernia.

Results:A total of 618 facet facet angles were measured, comprising 342 in the 57 patients in the LDH group and 276 in the 46 subjects of the control group. In the LDH group, at the L3-4 level, no tropism was determined in $46(80.7 \%)$, moderate tropism in $9(15.7 \%)$ and severe tropism in $2(3.5 \%)$. At the L4-5 level, no tropism was determined in $36(63.1 \%)$, moderate tropism in $17(29.8 \%)$ and severe tropism in 4 (7\%). At the L5-S1 level, no tropism was determined in $33(57.9 \%)$, moderate tropism in $17(29.8 \%)$ and severe tropism in $7(12.2 \%)$. In the control group, at the L3-4 level, no tropism was determined in $40(87 \%)$, moderate tropism in $5(10.9 \%)$ and severe tropism in $1(2.2 \%)$. At the L4-5 level, no tropism was determined in $37(80.4 \%)$, moderate tropism in 8 $(17.3 \%)$ and severe tropism in $1(2.1 \%)$. At the L5-S1 level, no tropism was determined in $34(73.9 \%)$, moderate tropism in $7(15.2 \%)$ and severe tropism in $5(10.9 \%)$.

In the LDH group, the mean facet angle values were $40.4^{\circ}$ at L3-4, $42.7^{\circ}$ at L4-5 and $45.9^{\circ}$ at L5-S1 levels. In the control group, the mean facet angle values were $39.2^{\circ}$ at L3-4, $41.4^{\circ}$ at L4-5 and $43.9^{\circ}$ at L5-S1 levels.

Conclusion: Although facet joint tropism was seen at a higher rate in the LDH patients than in the control group, the difference was not statistically significant $(p>0.05)$. The results of the study did not suggest that facet tropism is a factor in the etiology of LDH.
\end{abstract}

Key words: Lumbar disk hernia, facet joint tropism, young adults, facet joint

Eroğlu A, Yılmaz I, Eseoglu M. An evaluation of the facet joint angle characteristics on the development of lumbar disc hernia in young patients. Pam Med J 2018;11(3):229-235

Özet

Amaç: Çalışmamızda lomber disk hernisi (LDH) olan genç hastalarda faset tropizmini ve faset tropizminin LDH gelişimindeki rolünü araştırmak amaçlanmıştır.

Gereç ve yöntem:LDH'si olan 20- 32 yaş arasındaki 57 hasta ile lomber disk hernisi olmayan sağlam olarak kabul ettiğimiz 46 hastanın lomber Manyetik Rezonans Görüntüleme (MRG) tetkiklerinde L3-4, L4-5, L5-S1 mesafesinde bilateral faset eklem açıları aksiyal planda ölçüldü. Karşılıklı her iki faset eklem açısı arasında fark $<7^{\circ}$ ise tropizm yok, $7^{\circ}-14^{\circ}$ arasında ise orta derece tropizm, $>14^{\circ}$ ise ağır tropizm olarak sınıflandırıldı.

Bulgular:LDH'li 57 hastada 342, kontrol grubu 46 hastada 276 olmak üzere toplam 618 faset açısı ölçüldü. LDH grubununda L3-4 seviyesinde, \%80.7'sinde $(n=46)$ tropizm olmadığı, \%15,7'sinde $(n=9)$ orta derecede tropizm olduğu, \%2'sinde ( $n=3.5)$ ağır derecede tropizm olduğu görüldü. L4-5 seviyesinde, \% 63.1'inde $(n=36)$ tropizm olmadığı, \%29.8'inde $(n=17)$ orta derecede tropizm olduğu, \%7sinde $(n=4)$ ağır derecede tropizm olduğu görüldü. L5-S1 seviyesinde \%57.9'unda $(n=33)$ tropizm olmadığı, \%29.8'inde $(n=17)$ orta derece tropizm olduğu, \%12.2'sinde $(n=7)$ ağır tropizm olduğu tespit edildi. Kontrol grubunda ise L3-4 seviyesinde, \%87'sinde $(n=40)$ tropizm olmadığı, \%10.9'unda $(n=5)$ orta derecede tropizm olduğu, \%2.2'sinde $(n=1)$ ağır tropizm olduğu tespit edildi. L4-5 seviyesinde, \%80.4'ünde $(n=37)$ tropizm olmadığı, \%17.3'ünde $(n=8)$ orta derecede tropizm olduğu, \%2.1'inde $(n=1)$ ağır tropizm olduğu görüldü. L5-S1 seviyesinde \%73.9'unda $(n=34)$ tropizm olmadığı, $\% 15.2$ 'sinde $(n=7)$ orta derece tropizm olduğu, \%10.9'unda $(n=5)$ ağır tropizm olduğu tespit edildi. LDH'li grupta faset açı ortalamaları L3-4'te 40.4; L4-5't; 42.7; L5-S1'de 45.9 idi. Kontrol grubu faset açı ortalamaları L3-4'te 39.2; L4-5'te 41.4; L5-S1'de 43.9 derece idi.

Sonuç: Çalışmamızda faset eklem tropizmi, LDH'li hastalarda kontrol grubuna göre bir miktar yüksek oranda görülüyor olmasına rağmen istatistiksel olarak anlamı olmadığını belirledik $(p>0.05)$. LDH etiyolojisinde faset tropizminin predispozan bir faktör olarak rol oynamadığını düşünmekteyiz.

Ahmet Eroğlu, Op.Dr. Department of Neurosurgery, Haydarpaşa Sultan Abdülhamid Education and Research Hospital, ISTANBUL, e-posta: drahmeteroglu@gmail.com (orcid.org/0000-0001-7848-1551) (Sorumlu yazar)

İlhan Yılmaz, Op.Dr. Department of Neurosurgery, Şişli Hamidiye Etfal Education and Research Hospital, ISTANBUL, e-posta: ilhanyumit@ gmail.com (orcid.org/0000-0001-5548-2228)

Metehan Eseoglu, Dr.Öğr.Üyesi, Medipol Universty, Department of Neurosurgery, ISTANBUL, e-posta: metehaneseoglu@gmail.com (orcid. org/0000-0003-0260-1988) ESEOGLU M. 
Anahtar sözcükler: Lomber disk hernisi, faset eklem tropizmi, genç erişkin, faset eklem

Eroğlu A, Yılmaz İ, Eseoglu M lomber disk hernisi olan genç hastalarda faset eklem açı özelliklerinin lomber disk hernisi gelişimindeki rolünün araştırılması. Pam Tıp Derg 2018;11(3);229-235.

\section{Introduction}

Degenerated lumbar disc hernia (LDH) is a table characterised by leg and lower back pain associated with spinal root entrapment [1]. It is commonly seen with increasing prevalence in adults aged $>20$ years and has been reported in literature at the high rate of $40 \%$ throughout the lifetime [2].

Facet joints are anatomic structures with an important role in the distribution of the load carried by the spine to the discs, ligaments and muscles. The lower lumbar facets bear a greater load compared to the higher levels [3]. Of the torsional forces in the spine, $30 \%-45 \%$ is borne by the bilateral facet joints [4]. The anatomic orientation of the lumbar facet joints has been shown to provide the basic function of these joints of the control and stabilisation of torsional forces [3,5]. Micro and macro trauma and postural causes formed by shear movements, flexion and rotational movements may play an important role in structural anomalies such as facet tropism.

Facet tropism was first described in 1967 by Farfan and Sullivan [6]. Facet joint tropism is defined as an asymmetry between the right and left facet joint angles in the vertebrae. The mean difference between the facet joint angles has been calculated in previous studies as a standard value (SV) and differences in the angles above the SV are classified as facet tropism [5, 7-10].

Lumbar degenerative spondylolisthesis, facet osteoarthritis and mechanical lower back pain have been stated as predisposing factors of facet tropism in previous studies [3, 11, 12]. The aim of this study was to investigate facet tropism in a young adult LDH patient group and to examine the role of facet tropism in LDH.

\section{Material and Method}

\section{Patient Group}

The study was approved by the Local Ethics Committee (17.10.2017/1723). The study included 57 patients with LDH, comprising $26(45.6 \%)$ males and $31(54.3 \%)$ females with a mean age of 25.46 years and a control group of 46 healthy individuals, comprising 20 (43.5\%) males and 26 (56.5\%) females with a mean age of 24.63 years. The LDH group consisted of patients with lower back and leg pain ongoing for $>3$ months who had been determined with LDH at single level of L4-5 or L5-S1 on Magnetic Resonance Imaging (MRI) examination. $\mathrm{LDH}$ was determined at L4-5 level in $27(47.3 \%)$ cases, and at L5-S1 level in $30(52.7 \%)$ cases. Of these $17(29.8 \%)$ were determined as extruded, 28 (49.1\%) as protruded and $12(21 \%)$ as sequestered. The control group consisted of patients who had undergone MRI because of lower back pain following mechanical loading, LDH was not determined and the pain had recovered within 3 weeks (Table 1). Patients were excluded from the study if there was a history of spondylolysis, spondylolisthesis, trauma, scoliosis, discitis or previous lumbar disc surgery.

\section{Facet Angle Measurements}

The patients in the LDH group and the control group were evaluated with MRI examination. Image data were obtained with 64-slice multi-slice MRI (Avanto 1.5 Tesla, Siemens, Germany). Slice thickness was $3 \mathrm{~mm}$. The bilateral facet joint angles of the patients were measured on axial images at L3-4, L4-5 and L5-S1 levels using the method described by Kong et al. [13]. The reference plane (RP) was defined as the line drawn from the centre of the disc structure passing the centre of the spinous process base. The facet line ( $F L)$ was defined as the line drawn between the anteromedial and posteromedial edges of the bilateral superior articular facets. On both sides, the angle between the two lines was defined as the facet joint angle (Figure 1). In order to get rid of measurement bias, two observers measured the facet angles and they were blinded to each other. Consistency of the values were evaluated by 'The Intra Class Correlation Coefficient' (ICC) test. ICC was calculated as 0.912 , that showed high consistency of the obtained two values. Therefore, arithmetic average of the results of the two observers were taken and the angle value was obtained. 
Table 1.Demographic characteristics of LDH and control group

\begin{tabular}{lll}
\hline Characteristic & LDH $(\mathrm{n}=57)$ & Controls $(\mathrm{n}=46)$ \\
\hline Average age & $25.46(20-30)$ & $4.63(21-32)$ \\
Gender (M/F) & $26 / 31$ & $20 / 26$ \\
DL (L4/5) & 27 & Absent \\
DL (L5/S1) & 30 & Absent \\
DL (L4/5 and L5/S1) & Absent & Absent
\end{tabular}

M: Man F:Female; DL: Disc Level

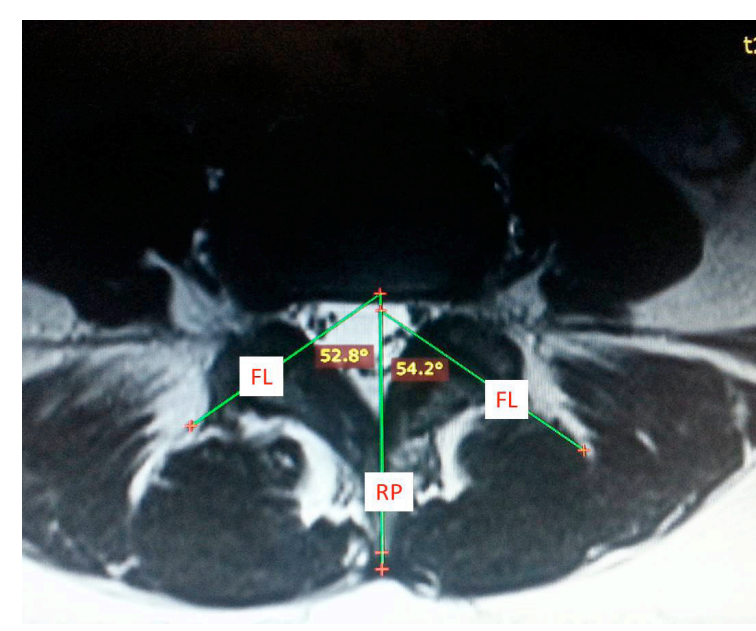

Figure 1. Reference plan (RP) is defined as the line passes in the midaxis of intervertebral disc and spinous process basis. Facet line $(F L)$ is defined as the line passes between anteromedial and posteromedial border of the bilateral superior articular facet. Facet joint angle (FJA) is defined as the angle between RP and $\mathrm{FL}$.

\section{Statistical Analysis}

The statistical analyses were conducted with SPSS version 15.0 statistics software. The power of the study was calculated using the online dss research calculator. Mean and standard deviation of all facet angles (342 measurements for the patient group and 276 for the control group) were calculated for the patient and control groups $(43.06 \pm 5.96$ and $41.55 \pm 5.58$ respectively). With an a error level of 0.05 , the power of the study was calculated as $98.8 \%$.

Continuous variables were stated as mean value \pm standard deviation (SD) and categorical variables as number $(n)$ and percentage (\%). The Kolmogorov-Smirnov test was used to assess conformity to normal distribution. Differences in continuous variables following normal distribution were examined using the $t$ test and differences in continous variables which did not conform to normal distribution were examined using the Mann Whitney-U test. Categorical variables were examined using the Chi-square test. A value of $p<0.05$ was considered statistically significant.

\section{Results}

Both male and female subjects were included in the LDH and control groups. The mean age of patients was 25.46 years in the LDH group and 24.63 years in the control group with no statistically significant difference between the groups $(p>0.05)$. A total of 618 facet angles were measured as 342 facet angles in 57 patients in the LDH group and 276 in 46 control group patients. The L3-4 measurements in the LDH group showed no tropism in $80.7 \%(n=46)$, moderate tropism in $15.8 \%(n=9)$ and severe tropism in $3.5 \%(n=2)$ of the patients. The L4-5 measurements in the LDH group showed no tropism in $63.2 \%(n=36)$, moderate tropism in $29.8 \%(n=17)$ and severe tropism in $7.0 \%(n=4)$ of the patients. The L5-S1 measurements in the LDH group showed no tropism in $57.9 \%(n=33)$, moderate tropism in $29.8 \%(n=17)$ and severe tropism in $12.3 \%(n=7)$ of the patients. In the control group, the L3-4 measurements showed no tropism in $87.0 \%(n=40)$, moderate tropism in $10.9 \%(n=5)$ and severe tropism in $2.2 \%(n=1)$ of the patients. The L4-5 measurements showed no tropism in $80.4 \%(n=37)$, moderate tropism in $12.4 \%(n=8)$ and severe tropism in $2.2 \%$ $(n=1)$ of the patients. The L5-S1 measurements showed no tropism in $73.9 \% \quad(n=34)$, moderate tropism in $15.2 \%(n=7)$ and severe tropism in $10.9 \%(n=5)$ of the patients (Table 2$)$. 
In the LDH group, the mean facet angle measurements were $40.44^{\circ} \pm 5.38^{\circ}$ at the L3-4 level, $42.82^{\circ} \pm 4.30^{\circ}$ at the L4-5 level and $45.95^{\circ} \pm 4.94^{\circ}$ at the L5-S1 level.

In the control group, the mean facet angle measurements were $33.27^{\circ} \pm 6,06^{\circ}$ at the L3-4 level, $41.41^{\circ} \pm 4,38^{\circ}$ at the L4-5 level and $43.98^{\circ} \pm 4.08^{\circ}$ at the L5-S1 level (Table 3). For the L3-4, L4-5 and L5-S1 levels of both groups, there was no difference between the right and left mean facet joint angles $(p>0.05)$. The frequency of facet tropism and the difference between the right and left facet joint angles for all 3 levels (L3-4, L4-5 and L5-S1) were determined to be similar in all the groups $(p>0.05)$. There was no significant change in facet joint angle differences at L3-4, L4-5 and L5-S1 levels ( $p>0.05)$. The mean facet joint angles increased significantly $(p<0.05)$ at lower levels in both groups.

\section{Discussion}

Disc herniation is defined as the exceeding of normal limits of the annulus fibrosus of the nucleus pulposus and other disc material (annulus fibrosus, end-plate) [15]. LDH is seen in the general population at the rate of $1 \%$ and is more often seen in males and in the $4^{\text {th }}-5^{\text {th }}$ decades of life. The viscous character of the nucleus pulposus and the elastic structure of the annulus fibrosus act as a functional unit and distribute the forces to which it is exposed along the axial skeleton [15].

Facet joints play a critical role in the stability and regulation of the movements of the vertebrae. Facet joint tropism is a difference in the angle between the right and left facet joints above the standard value (SV) $[3,8,10]$. When microtraumas occur in the lumbar region, structural anomalies such as facet tropism may play a significant role. Asymmetry which is

Table 2. Mean right and left facet angles, right and left facet angle differences and facet tropism in L3-4, L4-5 and L5-S1 level in LDH and control groups.

\begin{tabular}{|c|c|c|c|}
\hline & LDH group (n:57) & $\begin{array}{l}\text { Control } \\
\text { group (n:46) }\end{array}$ & $\mathbf{p}$ \\
\hline Right L 3-4 facet angle (in degrees) & $40.55 \pm 6.14$ & $38.59 \pm 7.20$ & $0.138^{*}$ \\
\hline Left $L$ 3-4 facet angle (in degrees) & $40.32 \pm 5.99$ & $39.94 \pm 5.70$ & $0.744^{*}$ \\
\hline L 3-4 facet angle difference (in degrees) & $4.48 \pm 3.34$ & $3.96 \pm 2.71$ & $0.399^{*}$ \\
\hline L 3-4 Tropism & & & $0.695^{\star *}$ \\
\hline none $(n)$ & $46(\% 80.7)$ & $40(\% 87.0)$ & \\
\hline moderate $(n)$ & $9(\% 15.8)$ & $5(\% 10.9)$ & \\
\hline severe $(n)$ & $2(\% 3.5)$ & $1(\% 2.2)$ & \\
\hline Right $L$ 4-5 facet angle (in degrees) & $42.93 \pm 6.08$ & $41.22 \pm 5.66$ & $0.146^{*}$ \\
\hline Left L 4-5 facet angle (in degrees) & $42.71 \pm 7.25$ & $41.61 \pm 4.45$ & $0.247^{*}$ \\
\hline L 4-5 facet angle difference (in degrees) & $5.63 \pm 4.06$ & $4.27 \pm 3.18$ & $0.036^{*}$ \\
\hline L 4-5 Tropism & & & $0.141^{* *}$ \\
\hline none $(n)$ & $36(\% 63.2)$ & $37(\% 80.4)$ & \\
\hline moderate $(n)$ & $17(\% 29.8)$ & $8(\% 12.4)$ & \\
\hline severe $(n)$ & $4(\% 7.0)$ & $1(\% 2.2)$ & \\
\hline Right L5-S1 facet angle (in degrees) & $45.81 \pm 5.68$ & $43.52 \pm 5.45$ & $0.181^{*}$ \\
\hline Left L5-S1 facet angle (in degrees) & $46.09 \pm 6.89$ & $44.45 \pm 5.06$ & $0.166^{*}$ \\
\hline L5-S1 facet angle difference (in degrees) & $6.17 \pm 4.80$ & $4.96 \pm 4.43$ & $0,192^{*}$ \\
\hline L5-S1 Topism & & & $0.185^{* *}$ \\
\hline none $(n)$ & $33(\% 57.9)$ & $34(\% 73.9)$ & \\
\hline moderate $(n)$ & $17(\% 29.8)$ & $7(\% 15.2)$ & \\
\hline severe $(n)$ & $7(\% 12.3)$ & $5(\% 10.9)$ & \\
\hline
\end{tabular}


Table-3: Mean angle measurements in LDH and control group by levels.

\begin{tabular}{cccc}
\hline Level & LDH Group & Control Group & p value* \\
\hline L3-4 & $40.44 \pm 5.38^{\circ}$ & $39.27 \pm 6.06^{\circ}$ & 0.301 \\
L4-5 & $42.82 \pm 4.30^{\circ}$ & $41.41 \pm 4.38^{\circ}$ & 0.105 \\
L5-S1 & $45.95 \pm 4.94^{\circ}$ & $43.98 \pm 4.08^{\circ}$ & 0.380 \\
\hline
\end{tabular}

*Student-T test

caused by facet tropism, causes an acceleration in lumbar degeneration and destruction of the disc structure by impairing the disc and facet structure with an increase in mechanical stress, and impairs balance and load distribution which is not homogenous, especially with repetitive movements in the lumbar region [16-18].

To determine facet tropism, the mean SV of the difference between the two facet joint angles is calculated and the SV difference has been shown in previous studies [8-10, 19]. In a study by Wang et al. [19], the SV was calculated as [10] and correspondingly, a difference of $<10^{\circ}$ between the 2 facet joint angles was accepted as no tropism and $>10^{\circ}$ as tropism. Ishihara et al. [9] reported that facet tropism could be accepted as a difference of $>1^{\circ}-10^{\circ}$ or when the SV was $>1$. Noren et al. [10] accepted facet tropism as a difference of $>5^{\circ}$ between the facet angles of the two sides. Grogan et al. [8] classified facet joint tropism in 3 stages. The SV was found to be 7 and correspondingly a difference between the 2 facet joint angles of $<7^{\circ}$ (1SV) was classified as no tropism, $7^{\circ}-15^{\circ}$ as moderate tropism and $>15^{\circ}$ (2SV) as severe tropism. In the current study, $1 \mathrm{SV}$ was calculated as $7^{\circ}$ and thus $<7^{\circ}$ was defined as no tropism, $7^{\circ}-14^{\circ}$ as moderate tropism and $>14^{\circ}$ as severe tropism.

In theory, symmetrical facets distribute the load equally bilaterally. As the obliquity of facet joints increases, they become less resistant to rotational forces [19-21]. Tropism in the facet joints prevents the equal distribution of loads and the stress created in unequal load distribution causes herniation and degeneration by affecting the disc structure in a long process $[16,18,22]$. In the presence of facet tropism, abnormal torsional movements have been reported to cause the unequal distribution of the load on the spine and degeneration of the intervertebral disc [16].
In addition to some authors who have accepted that facet tropism is a significant predisposing factor in the development of lumbar disc hernia [5, 9, 10, 23] there are also authors who have reported that facet tropism is not related to lumbar disc hernia development $[14,16,24]$.

Noren et al. [10] reported that there was a correlation between facet tropism and degeneration at all lumbarr levels and the development of disc hernia. Karacan et al. [5] found a high rate of facet joint tropism in patients with lumbar disc hernia. In another study by Wang et al. [23] of 65 young LDH patients and a control group of 30 volunteers, a relationship was found between facet tropism and $\mathrm{LDH}$ development. The control group consisted of patients who had undergone MRI because of lower back pain following mechanical loading in our study. This is the major drawback of the study. Ishihara et al. [9] examined facet tropism at 29 levels in 25 patients aged 12-20 years and at 50 levels in 33 patients aged $30-49$ years and reported a high rate of facet tropism in those wth $\mathrm{LDH}$ and lumbar disc degeneration, but these results were not compared with a group with normal discs.

However, in a study by Hagg [16] and Cassidy [24], no strong relationship was found between facet tropism and LDH, Vanharanta et al. [14] studied 108 patients using CT measurements and reported that facet angles increased caudally and there was no relationship between facet tropism and LDH and degeneration. Lee [17] also reported no relationship between facet tropism and LDH development in a study which compared facet tropism in a group with $\mathrm{LDH}$ and a normal group. In the currrent study, the presence of facet tropism was examined by comparing the facet angles in a group with 
$\mathrm{LDH}$ and a normal group. Although the rate of facet tropism was higher in the LDH patients, the difference between the two groups was not statistically significant ( $p>0.05)$.

In literature, facet tropism and the morphological structure associated with coronal and sagittal positions of the facet angles have been shown to have a provocative role in LDH [21, 25-27]. Studies have shown that the coronalisation of the facet joint facilitates the formation of $\mathrm{LDH}$ and sagittalisation has been shown to have a limiting and protective mechanism in cases developing LDH [24, 28]. Kenesi [29] found a significant relationship between facet joint sagittalisation and the mechanism leading to disc protusion only at the L5-S1 level. Farfan [6] and Cyron [30] showed that sagittal orientation of the facet discs could reduce the rotational forces which could be loaded on the disc, whereas coronal orientation could increase the loading of rotational forces on the disc.

Van Schaik [31] reported that L5-S1 with coronal location could cause more axial rotation of the facet joints and therefore could increase the amount of trauma to the disc. In the current study, it was found in both groups, that the facet joint angles increased towards the lower spaces, the facet joints came into a more coronal position and facet tropism was increased at the lower levels with the greatest coronalisation at L5-S1 related to the facet angulations. However, no statistically significant difference was determined when compared with other levels $(p>0.05)$.

In the majority of studies of tropism on LDH, the facet angles have been reported to increase at lower levels towards the inferior and the rate of facet tropism has been reported to be high at L4-5 and L5-S1 levels with LDH and a more coronal localisation of the facet joints. In the current study, the facet joint angles, the facet tropism rate and coronalisation increased at lumbar levels towards the inferior. Even if it is said that facet tropism plays a role in the formation of $\mathrm{LDH}$ because of a greater rate of facet tropism at the L5-S1 level, a more coronal localisation of the facet joint and that it is more affected by increasing the load on the vertebrae than by microtrauma, none of the statistical calculations made in the current study showed that facet tropism played a role in the development of LDH. In contrast to some studies in literature, facet joint tropism was not considered to have a role in LDH development.

\section{Declaration of conflicting interests}

The authors declared no conflicts of interest with respect to the authorship and/or publication of this article.

\section{Funding}

The authors received no financial support for the research and/or authorship of this article.

\section{References}

1. Postacchini F, Postacchini R. Operative management of lumbar disc herniation: the evolution of knowledge and surgical techniques in the last century. Acta Neurochir Suppl 2011;108:17-21.

2. Haidar R, Ghanem I, Saad S, Uthman I. Lumbar disc herniation in young children. Acta Pediatr 2010;99:1923.

3. Duc HD, Cyrus ET, Winston F. The relationship between degree of facet tropism and amount of dynamic disc bulge in lumbar spine of patients symptomatic for low back pain. Eur Spine J 2011;20:71-78.

4. O'Neill C, Owens DK. Lumbar facet joint pain: time to hit the reset button. Spine 2009;9:619-622.

5. Karacan I, Aydin T, Sahin Z, et al. Facet angles in lumbar disc herniation: their relation to anthropometirc features. Spine (Phila Pa 1976) 2004;29:1132-1136.

6. Farfan $\mathrm{H}$, Sullivan $\mathrm{J}$. The relation of facet orientation to intervertebral disc failure. Can J Surg 1967;10:179_ 185.

7. Don AS, Robertson PA. Facet joint orientation in spondylolysis and isthmic spondylolisthesis. J Spinal Disord Tech 2008; 21:112-115.

8. Grogan J, Nowicki BH, Schmidt TA, Haughton VM. Lumbar facet joint tropism does not accelerate degeneration of the facet joints. AJNR Am J Neuroradiol 1997;18:1325-1329.

9. Ishihara $H$, Matsui $H$, Osada $R$, Ohshima $H$, Tsuji $H$. Facet joint asymmetry as a radiologic feature of lumbar intervertebral disc herniation in children and adolescents. Spine (Phila Pa 1976) 1997;22:20012004.

10. Noren R, Trafimow J, Andersson GB, Huckman MS. The role of facet joint tropism and facet angle in disc degeneration. Spine (Phila Pa 1976) 1991;16:530-532.

11. Matsuo $Y$, Kaito T, Iwasaki M, Sugiura T, Fujimori T, Nagamoto $Y$, et al. 3D morphometric analysis of laminae and facet joints in patients with degenerative spondylolisthesis. Mod Rheumatol 2015;25:756-760. 
12. Poussa M, Schlenzka D, Seitsalo S, Ylikoski M, Hurri $\mathrm{H}$, Österman K. Surgical treatment of severe isthmic spondylolisthesis in adolescents. Spine 1993;18:894901.

13. Kong MH, He W, Tsai $Y$, Chen NF, Keorochana G, Do $\mathrm{DH}$. Relationship of facet tropism with degeneration and stability of functional spinal unit. Yonsei Med J 2009;50: 624-629.

14. Vanharanta $H$, Floyd $T$, Ohnmeiss DD, Hochschuler $\mathrm{SH}$, Guyer RD. The relationship of facet tropism to degenerative disc disease. Spine (Phila $\mathrm{Pa}$ 1976) 1993;15;18:1000-1005.

15. Donahue D, Whetsell W. Pathological considerations of the herniated nucleus pulposus. In :Camins and P. Oleary, Lumbar Spine. New York: Raven Press, 1987;427-437.

16. Hagg $O$, Wallner A. Facet joint asymmetry and protrusion of intervertebral disc. Spine 1990;15:356-359.

17. Lee DY, Ahn Y, Lee SH. The influence of facet tropism on herniation of the lumbar disc in adolescents and adults. J Bone Joint Surg Br 2006; 88:520-523.

18. Schleich C, Müller-Lutz A, Blum K, Boos J, Bittersohl B, Schmitt B. Facet tropism and facet joint orientation: risk factors for the development of early biochemical alterations of lumbar intervertebral discs. Osteoarthritis Cartilage 2016;24:1761-1768.

19. Wang $\mathrm{H}$, Zhou $\mathrm{Y}$. Facet tropism: possible role in the pathology of lumbar disc herniation in adolescents. J Neurosurg Pediatr 2016;4:1-5.

20. Adams MA, Hutton WC. The relevance of torsion to the mechanical derangement of the lumbar spine. Spine 1981;6:241-248.

21. Kim HJ, Kang KT, Son J, Lee CK, Chang BS, Yeom JS. The influence of facet joint orientation and tropism on the stress at the adjacent segment after lumbar fusion surgery: a biomechanical analysis. Spine J 2015;15(8):1841-1847.

22. Park JB, Chang $\mathrm{H}$, Kim KW, Park SJ. Facet tropism: a comparison between far lateral and posterolateral lumbar disc herniations. Spine 2001;26:677-679.

23. Wang $\mathrm{H}$, Zang $\mathrm{Z}$, Zhou $\mathrm{Y}$. Irregular alteration of facet orientation in lumbar segments: Possible role in pathology of lumbar disc herniation in adolescents. World Neurosurg 2016;86:321-327.

24. Cassidy JD, Loback D, Yong-Hing K, Tchang S. Lumbar facet joint asymmetry: intervertebral disc herniation. Spine 1992;17:570-574.

25. Dai LY. Orientation and tropism of lumbar facet joints in degenerative spondylolisthesis. Int Orthopaedics 2001;25:40-42.

26. Pichaisak W, Chotiyarnwong C, Chotiyarnwong P. Facet joint orientation and tropism in lumbar degenerative disc disease and spondylolisthesis. J Med Assoc Thai 2015;98:373-379.
27. Richard W, Jason C, Ben G, et al. An international multicenter study assessing the role of ethnicity on variation of lumbar facet joint orientation and the occurrence of degenerative spondylolisthesis in Asia Pacific: A study from the AOSpine Asia Pacific Research Collaboration Consortium. Global Spine J 2016;6:35.

28. Chadha M, Sharma G, Arora SS, Kochar V. Association of facet tropism with lumbar disc herniation. Eur Spine J 2013;22:1045-1052.

29. Kenesi C, Lesur E. Orientation of the articular processes at L4, L5 and S1. Possible role in pathology of the intervertebral disc. Anat Clin 1985;7:43-47.

30. Cyron BM, Hutton WC. Articular tropism and stability of the lumbar spine. Spine 1982;5:168-172.

31. Van Schaik JP, Van Pinxteren B. Curvature of the lower lumbar facet joints: variations at different levels and relationship with orientation. J Spinal Disord 1999;12:341-347. 